\title{
COMPARATIVE APPROACHES TO SOCIAL RESPONSIBILITY PROJECTS IN THE CONTEXT OF NEW PERFORMANCE CHALLENGES
}

\author{
Maria LOGHIN ${ }^{*}$, Răzvan Cătălin DOBREA ${ }^{b}$, Larisa OFIŢERU ${ }^{c,}$ Margareta FLORESCU ${ }^{d}$ \\ ${ }^{a, b, c, d}$ Bucharest University of Economic Studies, Romania
}

DOI: $10.24818 / \mathrm{IMC} / 2020 / 01.20$

\begin{abstract}
Corporate social responsibility represents one of the decisional factors in consumers preferences. During the time, organizations are creating their reputation based on their behavior related to social and environmental issues. Although the significance of the CSR is well-known, organizations don't use a common framework when integrating it in business strategies. In this study, we will analyze different models of implementing CSR in four countries - Belgium, Sweden, U.S.A and Austria. This approach is important for the development of the characteristics of a future CSR model in Romania, which will grow the performance of the organizations.
\end{abstract}

KEYWORDS: challenge, model, performance, social responsibility project

\section{INTRODUCTION}

Corporate social responsibility is a voluntary strategy or a government regulation, which helps in corporate growth and at maintaining a competitive edge. Despite this fact, the benefits of using CSR in business strategy are normally seen in a long term, not in each quarter of the year and most of the management teams don't understand the importance of using sustainability in their daily activities (Cohen et. al., 2011).

This study attempts to emphasize how different countries with a high or at least medium index of sustainability (Belgium, U.S.A., Sweden and Austria) are addressing social responsibility projects and which are the weaknesses and strengths of each model analyzed in the context of new performance challenges. Other countries with a high index of sustainability are represented by Denmark, Finland, Norway, France and Portugal, but we will study them in a future research.

\section{DIFFERENT APPROCHES TO CORPORATE SOCIAL RESPONSIBILITY}

As a first practice of corporate social responsibility, we will analyze the strategy used by Belgium. Louche et. al. (2007) claimed that Belgium organizations are using a European and more specifically a continental model of welfare state, where social considerations between social partners are shaped by the law and the government is inclined to build a legal frame for CSR. Even so, according to the author, only a few Belgian organizations are using the three-pillar model of CSR - social, economic and environmental - as part of their business strategy. FEB survey is reflecting that in Belgium, companies are considering the legal frame of CSR imposed by the government enough and do not want to make efforts for going beyond the law. In terms of concrete implementation, Flemish organizations are putting a strong emphasis on few themes, namely employees' health and safety, waste recycling, staff training, work/life balance and are excluding issues related to human rights and issues related to developing countries (Louche et. al., 2007).

\footnotetext{
* Corresponding author. E-mail address: marialoghin1992@gmail.com
} 
Non-financial reporting is important for all stakeholders: people which are looking for a new job will be impressed to know that your company is making efforts in solving social or environmental issues, investors will really like to have a partner with a good reputation, while consumers prefer products created in a sustainable way. According to EY study (De Waele, 2020), in Belgium, only a couple of companies are publishing an Integrated Report, but the number is rising.

Another country with a high index in practicing corporate social responsibility is represented by Sweden. Swedish Institute (2013) states that many of today's Swedish companies are at the forefront in integrating a sustainable approach to business in their strategies and daily management and one of the main reasons is that the government has an active participation in the CSR regulations. As specified by law, companies are forced to take responsibility for human rights, labor or environmental issues, otherwise trade sanctions can be applied (http://www.greenfuture.sg/2011/12/02/learningfrom-swedens-success-and-experience-in-embracing-csr/). The other main reason for the success of CSR in Sweden is that big Swedish companies are going beyond the law, making efforts in crossing the legal framework shaped by government.

Sweden is using the four pillars model for CSR - anti-corruption, human rights, labor standards, environment and since 2007, after the Global Reporting Initiative, Swedish government is requiring toallstateownedenterprisestopresenttheirCSRreports(http:/www.greenfuture.sg/2011/12/02/learning -from-swedens-success-and-experience-in-embracing-csr/).

U.S.A is not using an integrated model of CSR at the strategic level in business. They totally trust organizations for assuming their economic, legal, ethical and social responsibilities (Forte, 2013). The presumption that a company will voluntarily act in a sustainable mode seems not to be always true if we take as example the associations of entrepreneurs from North America which prefer not to interfere in social or environmental issues (Madrakhimova, 2013).

Thus, in U.S.A the government doesn't tend to be heavy handed in CSR regulation, it just ensures effective coordination and partnership of organizations with individual bureaus and offices in order to harness the social and environmental responsible initiative (Camilleri, 2017). Thereby, American companies are initiating their own CSR model, having maximum autonomy in determining the activities related to sustainability. Camilleri (2017) argued that the major areas of responsible corporate conduct, supported by the team of U.S.A Bureau of Economic and Business Affairs in offering CSR coordination for companies are including: "good corporate citizenship", "human rights", "labor and supply chains", "anticorruption", "health and social welfare", "contribution to the growth and development of the local economy", "innovation, employment and industrial relations", "environmental protection", "natural resource governance", "transparency", "trade and supply chain management", "intellectual property", and the "women's economic empowerment".

Nowadays, climate changes represent one of the most stressful issues for society. U.S.A is also making efforts in adopting environmentally friendly technologies, but the forecasts are not positive because it is still at the bottom of the classification relative to other countries (Vlastelica, 2018).

On the other hand, in 2013, U.S.A companies were in the top of rankings regarding the number of published reports for non-financial data (Vartiak, 2016).

The last model that we will discuss is represented by the corporate social responsibility strategy in Austria.

Federal Ministry of Agriculture, Forestry, Environment and Water Management (2017) advocates that Austria has a quite a long history in what concern the commitment to the implementation of the CSR principles, because since the World Summit for Environment and Development in Rio de Janeiro in 1992 its main effort was to stop or reverse unsustainable trends in order to guarantee an ecologically, economically and socially successful future.

The foundation of the Austrian Business Council for Sustainable Development is offering coordination in integrating the principles of "sustainable development" in business strategy. Austria is using the three pillars model of CSR and we can observe that the focus of work is represented by "health services, social mechanisms, climate and energy" (Strigl, 2004). In Austria and the 2030 
Agenda, we can find as main objectives for the next years "digitalization" "youth and leaving no one behind", "climate action and adaptation to the climate change".

For encouraging transparency between organizations, the government is offering the Austrian Sustainability Reporting Award for the best sustainability reports published by Austrian companies (Austrian Federal Chancellery 2020).

Table 1. Budget allocated by each analyzed country for sustainability
\begin{tabular}{|l|l|c|c|}
\hline Nr. & \multicolumn{1}{|c|}{ Country } & $\begin{array}{c}\text { Budget allocated for } \\
\text { sustainability }\end{array}$ & Year \\
\hline 1 & Belgium & 275 million EUR & 2015 \\
\hline 2 & U.S.A. & 12 trillion U.S dollars & 2018 \\
\hline 3 & Austria & 34 billion U.S dollars & 2019 \\
\hline 4 & Sweden & 1.97 billion EUR & 2017 \\
\hline
\end{tabular}

Source: from (Garcia, 2020), (Norrestad, 2020), eurosif , ussif.

\section{DISCUSSIONS}

CSR is an internationally accepted concept, but its conception and implementation are influenced by the culture of each country and this has led to the existence of a variety of practices (Louche et. al., 2007).

As a first difference between the models analyzed, it can be observed that Belgium and Sweden features require the active participation of the state in the regulation of social and labor relations, which occurs at the level of country, industry and individual business, while U.S.A model is characterized by regulations at the enterprise level and to a much lesser extent on the level of industry or region. Austrian model seems to combine the features of Northern European countries with U.S.A principles. Excluding philanthropy from corporate social responsibility by Sweden and Belgium is another difference if we compare with U.S.A model where philanthropy is encouraged by relevant tax exemptions. Regarding the adoption of environmentally friendly technologies, U.S.A is at the bottom of classification. There are also big differences when we compare the budget allocated for sustainability.

Apart from the differences between the models discussed, we can see also some common features. One of them is represented by the fact that all countries analyzed are publishing sustainability reports, which means that they are including transparency principle in their business strategy. Moreover, corporate social responsibility plays an important role in organizations life, helping at corporate growth and maintaining a competitive edge. Range topics such as "health services, employment and industrial relations" are supported by all CSR models analyzed. The last common principle is that the government seems to be present in all CSR models analyzed, with the observation that a part of governments tend to be heavy handed, while others just provide guidance to companies and their stakeholders to engage in corporate citizenship.

One of the main reasons in introducing corporate social responsibility in Romania was the influence of multinational organizations which shift their culture at the local level (Ceptureanu et al., 2016). Some examples of CSR projects in Romania, as reported by CSR media are represented by: development of the 'parks of the future' by OMV Petrom, 'green spaces' developed by MOL Romania, "small facts" implemented by Hartmann Romania "after us" by Coca-Cola, "save children" by DENT ESTED.

Nowadays, Romanian's consumers prefer products from organizations which are sustaining a social cause or organizations that are not indifferent to societal or environmental issues (Ionescu, 2020).

We think that a plus which will grow the competitivity between organizations in our country will be given by adopting Sweden principles with the remark that philanthropy should play an important role in the corporation lifecycle. 


\section{CONCLUSION}

Active participation of the government in shaping a legal framework for CSR represents one of the main reasons for the success in implementing a sustainable strategy at the business level. The threepillar model of CSR needs to be reflected in the entire organization activities, including all stakeholders in this strategy. Transparency in sustainability reports can stimulate the competitivity between organizations.

\section{REFERENCES}

Austrian Federal Chancellery (2020). Austria and the 2030 Agenda.

Camilleri, M. A. (2017). Corporate Social Responsibility Policy in the United States of America. In Corporate Social Responsibility in Times of Crisis (pp. 129-143). Springer, Cham.

Ceptureanu, S. I., Melinte, C. S., Ceptureanu, E. G., \& Borisov, D. (2016). Capabilities of SMEs in Romanian clothing industry/Capabilitatile IMM-urilor din industria de imbrăcaminte din România. Industria Textila, 67(4), 265.

Cohen, E., Arşinel, D. G., \& Chitoşcă, M. (2011). Responsabilitatea socială corporatistă în sprijinul resurselor umane: un parteneriat necesar pentru dezvoltarea unor practici responsabile în afaceri. Curtea Veche.

De Waele, C. (2020, July 24). How are Belgian companies performing with regard to non-financial reporting? Retrieved November 1, 2020, from https://www.ey.com/en be/nonfinancialintegrated-reporting/how-are-belgian-companies-performing-with-regard-to-non-financialreporting

Federal Ministry of Agriculture, Forestry, Environment and Water Management (2017). A Sustainable Future for Austria - The Austrian Strategy for Sustainable Development.

Financial industry overview. In Eurosif. Retrieved November 5, 2020 from http://www.eurosif.org/sri-study-2016/belgium/

Forte, A. (2013). Corporate social responsibility in the United States and Europe: How important is it? The future of corporate social responsibility. International Business \& Economics Research Journal (IBER), 12(7), 815-824. https://doi.org/10.19030/iber.v12i7.7970

Garcia, A. (2020, June 10). The sustainable investment market in Austria is at historic levels.

Retrieved October 23, 2020, from https://born2invest.com/articles/sustainable-investmentmarket-austria-historic-levels/

Ionescu, I. (2020, Martie). Revista de Colectie 100 de Oameni Care Fac BINE. CSRmedia. Retrieved October 20, 2020, from http://www.csrmedia.ro/csrmedia-ro-a-lansat-revista-de-colectie-100de-oameni-care-fac-bine/

Learning from Sweden's success and experience in embracing CSR (2011, December 2). In GREENFUTURE. $\quad$ Retrieved November 10, 2020, from http://www.greenfuture.sg/2011/12/02/learning-from-swedens-success-and-experience-inembracing-csr/

Louche, C., Van Liedekerke, L., Everaert, P., Leroy, D., Rossy, A., \& d'Huart, M. (2007). CSR in Belgium: the institutional context and practices.

Madrakhimova, F. (2013). History of development of corporate social responsibility. Journal of Business and Economics, 4(6), 509-520.

Norrestad, F. (2020, Nov 9). Sustainability themed investments SRIs in Sweden 2011-2017. Retrieved October 10, 2020, from https://www.statista.com/statistics/425747/sociallyresponsible-investments-sweden-sustainability-themed/ 
Strigl, A. (2004), CORPORATE SOCIAL RESPONSIBILITY IN AUSTRIA. University for

Natural Resources and Applied Life Science. Retrieved November 15, from https://oin.at/_publikationen/PublikationenALT/Fachartikel/Strigl $\% 202004 \% 20 \mathrm{csr} \% 20 \mathrm{in} \% 20 \mathrm{a}$ ustria.pdf

Sustainable investing assets reach $\$ 12$ trillion as reported by the US SIF Foundation's biennial Report on US Sustainable, Responsible and Impact Investing Trends. The Forum for Sustainable and Responsible Investment. In ussif. Retrieve October 26, 2020 from https://www.ussif.org/files/US\%20SIF\%20Trends\%20Report\%202018\%20Release.pdf

Swedish Institute (2013, November). Facts about Sweden. Retrieved October 23, 2020 from https://www.sweden.se/wp-content/uploads/2013/11/CSR-high-resolution1.pdf

Vartiak, L. (2016). CSR reporting of companies on a global scale. Procedia Economics and Finance, 39, 176-183. Retrieved 24 October, from https://core.ac.uk/download/pdf/81146068.pdf

Vlastelica, R. (2018, April 20). The U.S. ranks near the bottom on this sustainability scorecard. Retrieved November 11, from https://www.marketwatch.com/story/the-us-ranksnear-the-bottom-on-this-sustainability-scorecard-2018-04-17 